\title{
Assessment of English Language Learning in 2013 Curriculum
}

\author{
Arif Bulan ${ }^{1, a^{*}}$, Maman Suryaman ${ }^{2}$, Enung Nurhasanah ${ }^{1, b}$, Mardiah $^{1, c,}$ and Hasan ${ }^{1, d}$ \\ 1a,b Department of English Education, STKIP Yapis Dompu, Indonesia \\ 2Department of Apllied Linguistics, State University of Yogyakarta, Indoensia \\ 1c Department of Informational Technology of Education, STKIP Yapis Dompu, Indoensia \\ 1dDepartment of Language Education and Indonesian Literature, STKIP Yapis Dompu, Indonesia \\ 1a*arifbulan1@gmail.com; b enunghasanah@gmail.com; c diahjapri@gmail.com; ‘Hasan23@gmail.com; ${ }^{2}$ Maman_surya@yahoo.com \\ *Corresponding Author \\ Whatsapp number: [082136659544]
}

How to Cite : Bulan, A., Suryaman, M., Nurhasanah, E., Mardiah, M., Hasan, H. (2020). Assessment of English Language Learning in 2013 Curriculum. International Journal for Educational and Vocational Studies, 2 (1), 91-97. DOI: https://doi.org/10.29103/ijevs.v2i1.2036

\section{ARTICLE HISTORY}

Received: 23 November 2019

Revised: 22 December 2019

Accepted: 26 January 2020

\section{KEYWORDS}

Assessment of learning; English Language Learning; 2013 Curriculum;

\begin{abstract}
This study aims to determine: (1) the implementation of the 2013 curriculum in the assessment of English learning conducted by teachers; (2) the implementation of the 2013 curriculum English learning assessment in terms of national examination results; (3) the implementation of the 2013 curriculum English learning assessment in terms of teacher stratum. This research is a survey research using a quantitative approach and supported by a qualitative approach. This research was conducted in 16 state high schools in Sleman Regency. The samples in this study were 34 English teachers, all of them had taught based on the 2013 curriculum. Data collection in this study used questionnaires, observations, document analysis and interviews. The data analysis technique used is quantitative and qualitative descriptive techniques. The results of this study indicate that: (1) the implementation of the 2013 curriculum in learning assessment gets an average score of 3.5 (very good). Learning assessment is carried out based on education assessment standards in the 2013 curriculum. (2) implementation of learning assessments that are in accordance with the 2013 curriculum in schools that have low, medium, and high national examination scores is included in the excellent category with an average percentage of $87.45 \%$; (3) the implementation of learning assessment that is in accordance with the 2013 curriculum in terms of the stratum of teachers, that non-civil servant teachers implement higher learning assessment than civil servant teachers.
\end{abstract}

This is an open access article under the CC-BY-SA license.

\section{INTRODUCTION}

Indonesia currently has a 2013 curriculum at every level of education, especially high school. Until now the 2013 curriculum has been used evenly at the school level because the initial implementation of the 2013 curriculum was carried out by the government gradually starting in 2013. Based on the results of a survey conducted by researchers that in 2018 each school has used the 2013 curriculum as a reference for learning and assessment, but not all class levels use the 2013 curriculum.

The implementation of the 2013 curriculum in Indonesia took place in three major waves, namely in 2013, 2016 and 2017 so that in 2018 all schools had used the 2013 curriculum. What needs to be known is that, as stated earlier, the 2013 curriculum was implemented in schools in stages, can be seen in the school category. In the 2013 curriculum implementation, schools can be divided into three categories. First, schools that fully implement the 2013 curriculum. Second, schools that have only half implemented the 2013 curriculum. Third, schools that have just implemented the 2013 curriculum.

The implementation of the curriculum must be in direct contact with the teacher (Altricther, 2005; Fullan, 2007; Sulaiman et al, 2017), because the teacher is a key implementer of the curriculum (Hamalik, 2013; Mulyasa, 2014). Curriculum changes that occur in the world of education will have the effect of changing many things, one of which is assessment of learning. Learning assessment is an obligation that must be present in every education unit. Learning assessment also cannot be separated from the teacher's role in conducting the assessment. In the 2013 curriculum perspective the teacher is not the only evaluator, 
but the evaluation is also done by the participant to himself and to other students. This means that there are many forms of learning assessment choices in the 2013 curriculum.

Assessment in the 2013 curriculum focuses on three aspects of assessment, namely the assessment of attitudes (social and spiritual), knowledge and skills. Three aspects of this assessment can be done during the learning process and at the end of learning, or commonly known as formative and summative assessment. In essence the assessment is an activity in finding information, analyzing and interpreting student learning outcomes (Azim, 2012; Daryanto, 2014; Doherty, 2014).

Learning assessment in the 2013 curriculum must refer to standards set by the Ministry of Education and Culture. In this case, the Ministry of Education and Culture has implemented regulations regarding Assessment Standards at the High School level in Minister of Education and Culture Regulation No. 22 of 2016. The intended evaluation is the assessment of learning outcomes. Assessment of learning outcomes by educators is the process of gathering information about student learning outcomes in spiritual attitude competencies and social attitudes, knowledge competencies, and skills competencies carried out in a planned and systematic manner, during the learning process and after learning.

Based on the Minister of Education and Culture Regulation No. 22 of 2016 the assessment breakdown includes attitude assessment is the assessment made by educators in obtaining descriptive information about student behavior. Knowledge assessment is an activity carried out by educators to measure students' mastery of knowledge, while skills assessment is an activity carried out by educators to measure the ability of students to apply knowledge in carrying out certain tasks. Therefore, the principle of appraisal is that it must be valid, objective, fair, integrated, open, holistic, systematic, accountable, and educative, so that this evaluation is what we call authentic evaluation.

Assessment of the learning process uses an authentic assessment approach (authentic assessment) that assesses the readiness of students, the process, and learning outcomes as a whole. The integrated assessment of the three components will illustrate the capacity, style, and learning outcomes of students who are able to produce instructional effects (instructional effects) on aspects of knowledge and the impact of accompaniment on aspects of attitude. The results of authentic assessment are used by teachers to plan remedial learning programs, enrichments, or counseling services. In addition, authentic assessment results are used as material to improve the learning process in accordance with Education Assessment Standards. Evaluation of the learning process is carried out during the learning process by using tools: observation sheets, peer questionnaires, recordings, anecdotal notes, and reflections. Evaluation of learning outcomes is carried out during the learning process and at the end of the lesson unit using methods and tools: oral / deed tests, and written tests. The final evaluation results are obtained from a combination of process evaluation and evaluation of learning outcomes (Permendikbud, 2016).

Based on the understanding referred to in the Permendikbud above, the learning assessment in the 2013 Curriculum uses authentic assessment. Authentic assessment in the view of Nurgiyantoro and Suyata (2011) emphasizes the measurement of learning outcomes in the form of learners' competencies to perform accordingly, not just to know something, in accordance with the subjects and competencies taught. According to Daryanto (2014) authentic assessment is a significant measurement of student learning outcomes for the realm of attitudes, skills and knowledge. This means that authentic assessment measures three main domains in the 2013 Curriculum. Meanwhile, McCarthy (2013) says that "Authentic assessments are designed not only to access student learning, in other words assessment is not only intended to access the students which students have reached but form an integral part of the curriculum and learning experience. "What was mentioned by McCarthy above emphasizes that authentic assessment is designed not only to measure student learning, not only to measure what students have achieved but authentic assessment includes all integral parts of the learning process and experience study.

Furthermore, McCarthy (2013) divides authentic assessment into two namely authentic assignment and authentic task. Authentic assignment is one which is similar to the task in the real world and authentic assessment tasks increase motivation, engagement, and retiation, creating an interactive learning environment where students learn from each other as well as from their lecturers and reading. Authentic assessment can be said as a very contextual assessment because the assessment can be taken based on the contextual assignment given by the teacher to students. In addition, authentic assessment can stimulate student motivation through interactive learning where students can learn from each other.

Authentic assessment does not only emphasize right and wrong answers, but how students apply their knowledge, skills and attitudes to overcome the problems they face in real situations. It was as emphasized by Jaedun, Hariyanto, and Nuryadin (2014), Authentic assessment is an assessment that requires learners not only to answer the test correctly, but also to apply their knowledge, skills and attitudes to solve their problems of everyday life or professional life in the future. An authentic assessment can be done through many types of assignments. Therefore, the important point of authentic assessment is that a similarity assignment is given in schools to the real-life context faced by learners.

In authentic assessment, the teacher is not only assessing students from one side, but must assess the entire teaching process. As revealed by Azim (2012) that Through authentic assessment, teachers can not only assess students' performance in the context, but also 
enhance their knowledge, skills, and attitudes which are important goals of science curriculum. Authentic assessment assesses both the outcomes and the process and provides the stakeholders (teacher, parents, students, and policy makers) the required information about the students' learning.

The research will answer three main questions including: (1) how is the implementation of the 2013 curriculum in the assessment of English learning conducted by teachers; (2) How is the implementation of the 2013 curriculum English Language learning assessment in terms of national exam results; (3) How the implementation of the 2013 curriculum English learning assessment is evaluated from the teacher stratum.

\section{METHODS}

\subsection{Research Types}

This research is a survey research. According to Creswell (2012) survey designs are procedures in quantitative research in which investigators administer a survey to a sample or to the entire population of people to describe the attitudes, opinions, behaviors or characteristics of the population. A survey research design is a quantitative study or numerical description in which the researcher organizes a survey of a sample and / or population population with the aim of describing trends, attitudes, or opinions of a population by studying a sample of that population. From the sample results, researchers draw conclusions from the population. Survey research emphasizes the characteristics of actions, not on why these characteristics exist or the reasons behind them (Wiersma \& Jurs, 2009). As for the characteristics of prostitution in this case is the real situation.

This survey research design uses cross-sectional survey design. According to Creswell (2012) in a cross-sectional survey design, the researcher collects data at one point in time. In this cross-sectional design, researchers collect data at a certain time.

This research uses a quantitative descriptive approach and is supported by a qualitative descriptive approach. In this approach, the first thing researchers do is collect and analyze quantitative data through questionnaires and observations, then followed by collecting and analyzing qualitative data through interviews and document analysis.

\subsection{Place and Time of Research}

This research was conducted at State Senior High Schools (SMAN) in Sleman Regency. The selection of Sleman Regency as a research site due to the availability of informants was one of the factors. There are seventeen Public High Schools (SMAN) that have implemented the 2013 Curriculum in Sleman Regency. Schools that have implemented the 2013 curriculum according to data obtained from the Sleman Regency Education Office include SMAN 1 Prambanan, SMAN 1 Kalasan, SMAN 2
Ngaglik, SMAN 1 Pakem, SMAN 1 Sayegan, SMAN 1 Godean, SMAN 1 Sleman, SMAN 1 Depok, SMAN 1 Minggir Sleman, SMAN 1 Mlati, SMAN 1 Ngaglik, SMAN 1 Ngemplak, SMAN 1 Turi, SMAN 1 Gamping, SMAN 1 Tempel, SMAN 1 Cangkringan, and SMAN 2 Sleman. The time of this research was carried out in the 2018/2019 school year..

\subsection{Population and Sample of Research}

The populations in this study were all English teachers in seventeen State Senior High Schools (SMAN) in Sleman Regency who had implemented the 2013 Curriculum. Based on data from Department of Education and Culture of Sleman Regency in 2018 that there were a population of 50 English teachers, but the sample which were recruited in this study were 34 teachers.

\subsection{Data Collection Technique}

Data collection techniques in this study used non-test techniques in the form of questionnaires / questionnaires, interviews, observations, and document analysis. Questionnaire technique is a set of questions or written statements given to respondents with the aim of expressing the situation and the impression that exists within the respondent as well as outside himself.

The questionnaire in this study was used to obtain data on learning planning, and assessment of learning in the implementation of the 2013 Curriculum on English Subjects of State Senior High Schools in Sleman district. The instrument used in the questionnaire in this study uses a closed questionnaire in which respondents provide answers in accordance with what is felt through the choice of answers that have been provided.

Observation technique is carried out to get data about the learning process. Observations in this study put researchers as non-participatory observers. Non-participatory observation, that is, researchers mingle with students in class and follow the learning process. Therefore, the instrument used in observation uses a checklist. The document analysis technique is used to obtain data supporting the implementation of the 2013 curriculum in English subjects.

Interview techniques are used to obtain more detailed and in-depth information from respondents. The interview was conducted by structured interview. In a structured interview questions are asked to the respondent in this case the English teacher, each key respondent is given the same question. The instruments used in the interview use structured interview guidelines, meaning that the questions raised in the interview process with respondents have been prepared in advance.

\subsection{Research Instrument}

Research instruments are tools that can be used to collect and obtain data and information. The instruments used in this study were closed questionnaire sheets, observation 
sheets, structured interview guidelines and document analysis. The closed questionnaire sheet contains several questions regarding the learning planning and learning sub-variables by providing an answer column for respondents. Respondents in the study were English teachers who had participated in the 2013 curriculum training and socialization. In this closed questionnaire, respondents were free to give answers in the columns that were available.

The observation sheet in this study is in the form of notes to record the results of observations made by researchers during the learning process in the classroom. The observation sheet is filled in by the researcher himself by looking at and observing conditions that are in accordance with the conditions that occur during the learning process, meaning that the researcher is present in an open observation where the researcher mingles and follows the learning process.

Interview guidelines in this study are structured question items, meaning that the questions in the interview follow the guidelines compiled by researchers to get data from the implementation of the 2013 curriculum in English subjects. Meanwhile, document analysis was carried out in this study through a checklist to see the completeness of 2013 curriculum documents.

\subsection{Validity and Reliability of Instruments}

The validity of an instrument refers to the extent to which an instrument can measure what it wants to measure. According to Allen and Yen (1979: 97) there are three types of validity, namely content validity, construct validity and criteria validity. The validity used in this research is content validity. Content validity is used to determine the extent to which the instrument reflects the expected content. As explained by Miller, Linn, and Grondlund (2009) that content validity aims to determine the extent to which a series of studies provides a relevant and representative sample of all the behavioral domains that it represents.

The validity of the content relates to the question to what extent the test items cover the entire material or material to be measured. The extent to which a test has proof of validity is determined according to a rational analysis of the contents of the test, the assessment of which is based on the subjective judgment of individual experts in the field being measured so that the results can be justified (Mardapi, 2012) The contents of the instruments in this study have been considered by experts in their fields in order to test whether the instrument items are valid or not to measure the variables to be measured. The variable measured in this study was the implementation of the 2013 curriculum which included two sub-variables namely learning planning and learning assessment.

The instrument reliability test in this study was to measure the consistency of the instruments in measuring the variables of learning planning, learning process and learning assessment. Internal consistency according to Mardapi (2012) only requires one test presentation. The instrument reliability test in this study was carried out using the internal consistency method, the data was then analyzed using the IBM SPSS Statistics 21 software through the results of the Cronbach Alpha calculation. Data is said to be reliable if the results of the Alpha Cronbach calculation (reliability value) symbolized by $\rho$ meet the requirements of $-1.00 \leq \rho \leq+1.00$ (Retnawati, 2015). Based on calculations, as in the table below, it can be concluded that all instruments are reliable, so the research instruments are feasible to use for data collection.

\subsection{Data Analysis Techniques}

Data analysis techniques in this study used quantitative descriptive analysis which was supported by qualitative analysis. Quantitative and qualitative descriptive analysis is done by describing and interpreting the data of each sub variable. Before being analyzed, the data from the questionnaire were first quantified using statistical descriptive techniques, then the interview data and document analysis were analyzed with qualitative analysis.

The results of calculations in data analysis produce achievement values which are then interpreted. Changing the average value and achievement on each indicator into the achievement category using the Norm Reference Guidelines (PAN) adopted by researchers from Nurgiyantoro (2012), namely in the scale of the assessment of conversion guidelines for PAN can be on a scale of four, five, nine, ten, eleven and a hundred. According to Sugiyono (2013) the Likert scale uses 4 scales that are modified into four alternative answers, which are always, often, rarely, and never by removing alternative doubtful answers, because it is feared that respondents take the path or choose the alternative and do not have the answers extreme. Therefore, in this study the researchers chose to use a scale of four with answer choices always (SL), often (SR), rarely (JR) and never (TP) for choice of answers in a questionnaire. The following interval guidelines are used as shown in the table below

Tabel 1. Scale Four Conversion Guidelines

\begin{tabular}{ccc}
\hline Scale & Score interval & Category \\
\hline 4 & $\mathrm{ST} \geq \mathrm{X} \geq \mathrm{Mi}+1,5 \mathrm{SDi}$ & Very good \\
\hline 3 & $\mathrm{Mi}+1,5 \mathrm{SDi}>\mathrm{X} \geq \mathrm{Mi}$ & good \\
\hline 2 & $\mathrm{Mi}>\mathrm{X} \geq \mathrm{Mi}-1,5 \mathrm{SDi}$ & Less good \\
\hline 1 & $\mathrm{Mi}-1,5 \mathrm{SDi}>\mathrm{X} \geq \mathrm{SR}$ & Not good \\
\hline
\end{tabular}

(adopted from Nurgiyantoro, 2012).

Mi (X) : Mean ideal 1/2 (ST + SR)

SDi (s) : Standard of Deviation ideal 1/6 (ST - SR)

ST : Ideal Highest Score

SR : Ideal Lowest Score 


\section{RESULTS AND DISCUSSION}

\subsection{Implementation of 2013 Curriculum in Learning Assessment}

In the implementation of the 2013 curriculum in the assessment of learning there are three aspects of assessment. First assessment planning, which includes the preparation of the attitude assessment instrument, knowledge and skills, rubric of attitude assessment instrument, knowledge and skills, selection of assessment techniques in accordance with indicators of competency achievement, determination of procedures for evaluating student learning outcomes according to KKM. Second, the application of assessment, which includes the application of authentic assessment, the application of daily assessment, the application of midterm assessment and the application of end of semester assessment, remedies for students who have not met the indicators of competency achievement. Third, reporting the assessment results.

Table 2. The analysis of the implementation of the 2013 curriculum in learning assessment

\begin{tabular}{ccc}
\hline & \multicolumn{2}{c}{ Learning Assessment } \\
\cline { 2 - 3 } Score & Amount of teacher & percentage \\
\hline$S T \geq X \geq M i+1,5$ SDi & 29 & $85,29 \%$ \\
\hline$M i+1,5$ SDi $>$ X $\geq M i$ & 5 & $14,71 \%$ \\
\hline$M i>X \geq M i-1,5$ SDi & 0 & 0 \\
\hline$M i-1,5$ SDi $>X \geq S R$ & 0 & 0 \\
\hline Total & 34 & $100 \%$ \\
\hline
\end{tabular}

Data on the implementation of the 2013 curriculum in the assessment of learning at state high schools in Sleman based on the table above was measured using a questionnaire totaling 14 statements using a Likert scale modified with a score of 1 to 4 . The questionnaire was distributed to 34 respondents and analyzed using Microsoft software excel. Based on the above table it can be seen that there are $85.29 \%$ of teachers who have implemented the 2013 curriculum learning assessment very well, and there are $14.71 \%$ of teachers who have implemented the 2013 curriculum learning assessment well. Data from the questionnaires that have been distributed obtained an average value of 3.5. This shows that the implementation of the 2013 curriculum in English subjects in the assessment of learning in State Senior High Schools in Sleman Regency was included in the very good category.

The 2013 curriculum English learning assessment is an assessment of student learning outcomes which includes three domains of competence, namely attitude competence, knowledge and skills whose implementation must be integrated with the learning process. Assessment of learning English by teachers is expected to refer to the Ministry of Education and Culture. No. 23 of 2016 concerning education assessment standards that emphasize that assessment is the process of gathering and processing information to measure the achievement of student learning outcomes.

The 2013 curriculum English learning assessment not only focuses on final grades, but also assesses the learning process. This assessment is integrated between the two, in which the decision to score is not only based on the aspects of knowledge and skills seen at the end of the semester assessment, but also on the daily and midterm assessments. While attitude assessment can be done with observation sheets, peer assessments and also assessments from other teachers if deemed necessary. Based on the interview results obtained, the teacher also conducts an attitude assessment by asking or asking other teachers related attitudes of certain students. According to Havnes et al (2012) that assessment must be made clearly about what is obtained by students.

Based on the results of the study note that the assessment of learning English related to attitude competence, knowledge and skills included in the category of very good, these results are supported by interviews with respondent teachers, teachers conduct attitude assessments with student observation sheets, peer assessments, and assessments from teachers other. In addition, it is also supported by the completeness of documents where teachers often compile student assessment rubrics and also have a list of grades documents. Completeness of the assessment document will assist teachers in analyzing, interpreting and monitoring thoroughly both in the realm of attitudes, knowledge and skills, also helps teachers in making improvements related to individual and or group student attitudes and improvements in learning strategies so that teachers are able to see the achievement of competencies knowledge and skills. According to Daryanto (2014) assessment is a series of activities to obtain, analyze, and interpret data about the processes and learning outcomes of students that are carried out systematically and continuously so that it can be meaningful information in making decisions.

\subsection{Implementation of Learning Assessment in Terms of National Examination Results}

Based on this analysis, the data was obtained through a questionnaire by looking at the implementation of the 2013 
curriculum in the assessment of learning English in terms of three main indicators namely assessment planning, implementation of the assessment, and reporting the results of the assessment. The assessment planning indicators consist of formulating an attitude assessment instrument, knowledge and skills, compiling an assessment instrument rubric of attitude, knowledge and skills, selecting assessment techniques in accordance with indicators of competency achievement, determining the procedure for evaluating student learning outcomes according to KKM. Indicators of the implementation of the assessment consist of the application of authentic assessment, the application of daily assessment, the application of mid-semester assessment and the application of end-of-semester assessment, remedies for students who have not met the indicators of competency achievement. The last indicator is reporting the assessment results.

In general, the implementation of the 2013 curriculum in the assessment of learning English in terms of high schools that scored low in the 2016 National Examination was included in the excellent category with a percentage of implementation of $86.48 \%$. Likewise, state high schools that received national examination scores were included in the very good category with a percentage of implementation of $88.52 \%$. Whereas the implementation for schools that received a high national examination included in the very good category was a percentage of $87.36 \%$. Although the three categories of schools had implemented the 2013 curriculum in the learning process very well, schools that received national examination scores in the category were implementing the 2013 curriculum in learning assessment with highest percentage value.

Based on the 2013 curriculum questionnaire analysis in the assessment of English language learning in terms of the results of the 2017 National Examination, it can be seen that the implementation of the 2013 curriculum in the assessment of learning in schools that have low national examination scores is included in the excellent category with a percentage of $86.48 \%$, while in schools that received the national examination score were in the very good category with a percentage reaching $88.52 \%$, while in schools that received a high national examination score were included in the very good category with a percentage of $87.36 \%$. The average value is $87.45 \%$. The data above was obtained from the results of an English learning assessment questionnaire at the State Senior High School in Sleman regency. The data was analyzed using Microsoft Excel software. Based on these data it can be concluded that the implementation of learning assessments that are in accordance with the 2013 curriculum in schools that have low, medium and high national examination scores is included in the excellent category.

Based on the results of the analysis of each statement item on the questionnaire about the implementation of the 2013 curriculum in learning assessment, it was found that item number 5 has the lowest mean value in learning assessment. From the questionnaire analysis data it is known that statement number 5 in the assessment of learning regarding attitude competency assessment uses peer assessment sheets. Based on item 5 in the above statement it can be concluded that in the assessment of learning, teachers in schools that obtain national examination scores are low, medium and high lacking in the implementation of learning assessment using peer assessment for attitude competency.

\subsection{Implementation of Learning Assessment in terms of Teacher Stratum}

Based on this analysis, the data was obtained through a questionnaire by looking at the implementation of the 2013 curriculum in the assessment of learning English in terms of the stratum of civil servant and Non-civil servant teachers. The main indicators that exist in the assessment of learning are assessment planning, implementation of assessment, and reporting the results of the assessment. The assessment planning indicators consist of formulating an attitude assessment instrument, knowledge and skills, compiling an assessment instrument rubric of attitude, knowledge and skills, selecting assessment techniques in accordance with indicators of competency achievement, determining the procedure for evaluating student learning outcomes according to minimal completeness criteria (KKM). Indicators of the implementation of the assessment consist of the application of authentic assessment, the application of daily assessment, the application of mid-semester assessment and the application of end-of-semester assessment, remedies for students who have not met the indicators of competency achievement. The last indicator is reporting the assessment results.

In general, the implementation of the 2013 curriculum in the assessment of learning English in terms of stratum, civil servant teachers included in the category of very good with the percentage of implementation of $87.26 \%$. Meanwhile Non-civil servant teachers are included in the excellent category with a percentage of implementation of $90.62 \%$. Although between civil servant and Non-civil servant teachers have implemented the 2013 curriculum in learning assessment very well, Non-civil servant teachers got the highest percentage score compared to Civil servant teachers.

Based on the 2013 curriculum questionnaire analysis in the assessment of English learning in terms of the stratum of civil servant and Non-civil servant teachers, it can be seen in the picture above that the implementation of the 2013 curriculum in the learning assessment reviewed from civil servant teachers is included in the very good category with a percentage of $87,26 \%$, while the Non-civil servant teachers are included in the excellent category with a percentage of $90.26 \%$. The average value is $88.76 \%$. This data was obtained from the results of a questionnaire analysis of the assessment of English learning in state senior high schools in Sleman regency. The data was analyzed using Microsoft Excel software. Based on these data it can be concluded that the implementation of learning assessments that are in accordance with the 2013 
curriculum in terms of the stratum of teachers, that Non-civil servant teachers are higher in the implementation of learning assessments than Civil servant teachers.

Based on the analysis of each statement item on the questionnaire about the implementation of the 2013 curriculum in the assessment of learning for civil servant teachers, it was found statement items number 5 and 9 had the lowest mean value in learning assessment. From the questionnaire analysis data it is known that statement number 5 in the assessment of learning regarding attitude competency assessment uses peer assessment sheets and item number 9 in the assessment of competency skills using project appraisal. Peer evaluation is actually an assessment model that gives students the opportunity to assess other students, peer assessment is only limited to the realm of attitude where the teacher acts as a facilitator in preparing assessment forms that have been made by the teacher. This is as expressed by Daryanto (2014) that the assessment between friends is an assessment conducted on the attitudes of students by other students in one class or study group. This assessment trains students to become good learners by actively helping the teacher in assessing other students as material for consideration and decision making by the teacher. While project appraisal is a model of assessment conducted by teachers to assess students' skills, in the context of the 2013 curriculum project appraisal as expressed by Daryanto (2014) focuses more on student assessment in selecting topics, searching and collecting data, processing and analyzing and writing reports using checklist instruments, rating scales or narratives. Based on the statement point number 5 and number 9 in the statement above it can be concluded that in the assessment of learning, civil servant teachers lacking in the implementation of learning assessment using peer assessment for attitude competence and the implementation of learning assessment using project assessment for skills competence.

\section{REFERENCES}

Altrichter, H. (2005). Curriculum implementation, limiting and facilitating factors. Austria: Johannes Kepler University.

Azim, S. (2012). Authentic assessment: An approach to enhance and access learning. Germany: Lambert Academic Publishing.

Creswell, J.W. (2012). Educational research: Planning, conducting, and evaluating quantitative and qualitative research (4th ed). Boston, MA: Pearson Education, Inc.

Daryanto. (2014). Pendekatan pembelajaran saintifik kurikulum 2013. Yogyakarta: Penerbit Gava Media.

Doherty, I. (2014). Proffesional development: Designing for the cognitive and affective domains [Versi elektronik]. Journal of Learning Design, 7, 1-15.

Fullan, M. (2007). The new meaning of educational change. New York: Teacher Collage Press.
Hamalik, O. (2013). Dasar-dasar pengembangan kurikulum (cet. Ketiga). Bandung: PT Remaja Rosdakarya.

Havnes, A., Smith, K., Dysthe, O., et al. (2012). Formative assessment and feedback: Making learning visible [Versi elektronik]. Journal of Studies in Educational Evaluation, 38, 21-27.

Jaedun, A., Hariyanto, L., \& Nuryadin, E.R. (2014). An evaluation of the implementation of curriculum 2013 at the building construction department of vocational high schools in Yogyakarta [Versi elektronik]. Journal of Education, 7, 14-22.

Mardapi, D. (2012). Pengukuran, penilaian \& evaluasi pendidikan. Yogyakarta: Nuha Litera.

McCarthy, G. (2013). Authentic assessment - key to learning. In E. Doyle, P. Buckley \& C. Carroll (Eds.), Innovative Business School Teaching - Engaging the Millennial Generation (pp. 81-92). United Kingdom: Routledge.

Miller, M.D., Linn, R.L., \& Grondlund, N.E. (2009). Measurement and assessment in teaching (10 $10^{\text {th }}$ ed). Upper Saddle River New Jersey: Pearson Education Inc.

Mulyasa, E. (2014). Pengembangan dan implementasi kurikulum 2013 (Cet. Keempat). Bandung: PT Remaja Rosdakarya Offset.

Nurgiyantoro, B. (2012). Penilaian pembelajaran bahasa berbasis kompetensi (cet. Kelima). Yogyakarta: BPFE Yogyakarta.

Nurgiyantoro, B. \& Suyata, P. (2011). Model penilaian autentik dalam pembelajaran bahasa [Versi elektronik]. Jurnal LITERA, 10, 114-125.

Permendikbud. (2016). Salinan Lampiran Peraturan Menteri Pendidikan dan Kebudayaan Nomor 22 Tahun 2016 tentang Standar Proses Pendidikan Dasar dan Menengah.

Retnawati, H. (2015). Validitas, reliabilitas dan karakteristik butir: Panduan untuk peneliti, mahasiswa, dan psikometri. Yogyakarta: Parama Publishing.

Sulaiman, S., Sulaiman, T., \& Abdul Rahim, S.S. (2017). Teacher' perception of the standard-based English language curriculum in Malaysian primary school [Versi elektronik]. International Journal of Instruction, 10, 195-208.

Wiersma, W. \& Jurs, S.G. (2009). Research Method In Education: An Introduction (9th eds.). Boston: Pearson Merril Prentice Hall. 